\title{
DISEMINASI INKLUSI KEUANGAN DAN PENGEMBANGAN KUALITAS SUMBER DAYA MANUSIA KOPERASI SMP 83
}

\author{
${ }^{1}$ Arif Surahman, ${ }^{2}$ Agustina Mogi, ${ }^{3}$ Muhammad Yuda Alhabsyi, \\ ${ }^{4}$ Eko Cahyadi, ${ }^{5}$ Hengki Hermawan \\ Dosen Fakultas Ekonomi Universitas Pamulang \\ Email : $\underline{\text { arifsurahman9@gmail.com }}$
}

\begin{abstract}
ABSTRAK
Permasalahan utama yang dihadapi oleh Koperasi SMP 83 adalah sebagai berikut : A. Koperasi menghadapi masalah publikasi dan eksistensi dalam keragaman produk pembiayaan kepada anggotanya. B. Koperasi perlu lebih banyak mengetahui mengenai inklusi keuangan. C. Koperasi memiliki mutu sumberdaya yang rendah dalam mengelola pembiayaan yang telah diberikan. Beberapa langkah yang ditempuh sebagai metode untuk melaksanakan solusi terhadap permasalahan yang dihadapi yayasan akan dilakukan dengan beberapa hal berikut ini:1. Sosialisasi Program 2. Koordinasi 3. Pelaksanaan Program 4. Evaluasi Program.

Hasil dari pengabdian kepada masyarakat ini adalah berubahnya pola pikir dan wawasan dari peserta yang mengikuti penyuluhan sebagaimana dibuktikan dengan adanya games dan challenge untuk menguji kemampuan dan wawasan peserta PKM.
\end{abstract}

\section{Kata Kunci : Inklusi, Keuangan, Pengembangan, Kualitas, Pinjaman.}

\section{PENDAHULUAN}

Didalam Undang-Undang Dasar 1945 koperasi merupakan lembaga perekonomian yang diamanatkan untuk menjadi kekuatan ekonomi masyarakat. Cita-cita luhur dari koperasi Indonesia adalah membebaskan masyarakat dari jeratan hutang rentenir dan cita-cita ini terus menghadapi tantangan yang beragam dari tahun ke tahun (Sitepu \& Hasyim, 2018). Dunia perbankan dapat berkolaborasi dengan koperasi sehingga terdapat win-win solution yang sama-sama menguntungkan bagi kedua belah pihak. " Ketua Koperasi "Oryza Sativa" Dinas Pertanian dan Kehutanan Kabupaten Bogor, Engkus Kusminar mengatakan meskipun koperasi tidak memiliki agunan, terdapat dua gagasan yang perlu dipertimbangkan oleh pihak bank dalam melihat peluang terjalinnya harmonisasi kerjasama dengan koperasi. Pertama, bank bertindak sebagai executing berarti pihak bank memberikan pinjaman kepada koperasi berupa saldo yang kemudian kami pinjamkan ke anggota dengan sistem pemotongan gaji langsung untuk membayarnya.Yang kedua, kata Engkus adalah dengan cara geneling, yang berarti setiap anggota koperasi kepegawaian bisa secara langsung meminjam sejumlah dana kepada bank seperti biasa namun pihak bank memberikan syarat menyertakan keanggotaan koperasi dan pihak bank mengadakan bagi hasil dengan koperasi (Susanti\&Fajar, 2016)". Akibat dari sinergi ini, maka baik dunia perbankan maupun 
dunia koperasi dapat menghasilkan produk-produk pembiayaan dan tabungan yang lebih bervariasi dan lebih inovatif sehingga sama-sama akan mengembangkan kualitas produk dari koperasi dan kualitas produk dari bank.

Disisi lain, koperasi juga perlu untuk mengembangkan kualitas sumberdaya anggotanya, supaya pinjaman-pinjaman yang macet dapat berkurang. Pengetahuan didunia barat telah memodernisasi bagaimana cara seseorang untuk belajar.

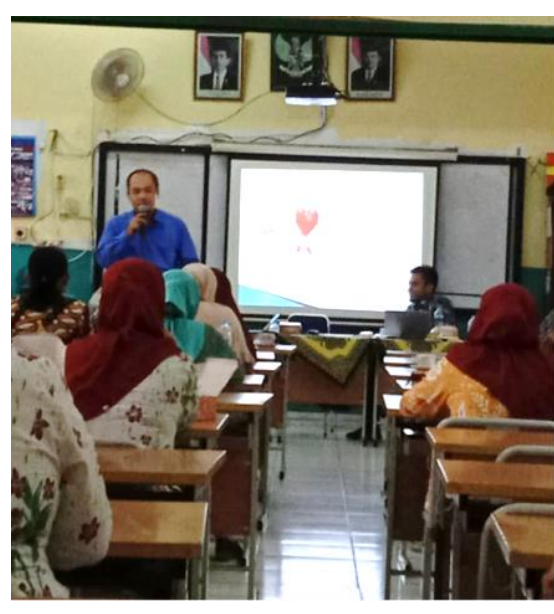

Gambar 1. Presentasi Seseorang yang bernama Tony Buzan telah menemukan cara revolusioner untuk meningkatkan kemampuan belajar. Peningkatan kualitas sumber daya manusia ini juga bagus bagi reputasi kerjasama antara koperasi dengan dunia perbankan. Sehingga apabila kualitas kredit koperasi sudah bagus, maka bank tidak akan berpikir dua kali untuk bekerjasama dengan koperasi.

Kerjasama dengan perbankan akan semakin menguntungkan, sehingga uang koperasi bisa ditaruh di bank yang melakukan kerjasama dan para anggota koperasi bisa langsung dipotong gajinya oleh bank untuk dimasukkan kedalam rekening koperasi untuk selanjutnya disalurkan dalam bentuk pendanaan kepada anggota koperasi.

Pengetahuan tentang inklusi keuangan perlu didesiminasikan oleh dunia akademisi, supaya semua orang paham dan bisa memperoleh pinjaman untuk melakukan bisnis dan keluar dari kemiskinan. Untuk memiliki keunggulan dalam pengelolaan kredit, maka para pengelola dana yang meminjam harus merevolusionerkan caranya belajar dengan menggunakan metode belajar yang bisa meningkatkan kemampuannya untuk mencerna informasi dengan baik. Oleh karena itu, kami dari Dosen Universitas Pamulang bermaksud untuk melakukan pengabdian masyarakat dengan judul "Diseminasi Inklusi Keuangan dan Pengembangan Kualitas Sumber Daya Manusia Koperasi SMP 83."

\section{METODE PELAKSANAAN KEGIATAN}

Metode pelaksanaan akan ditempuh dengan melakukan penyuluhan dan pelatihan kepada anggota koperasi SMP 83. Bentuk partisipasi dari koperasi yang diharapkan pada waktu kegiatan ini adalah penyediaan perlengkapan dan sarana prasarana pendukukung yang dibutuhkan untuk melaksanakan kegiatan PKM.

Setelah rangkaian acara kegiatan PKM dilakukan, maka akan dilakukan proses evaluasi. Bentuk dari evaluasi yang akan dilakukan adalah dengan pengunjungan berkala dan pelatihan yang lanjutan dalam bentuk Pengabdian Kepada Masyarakat. 


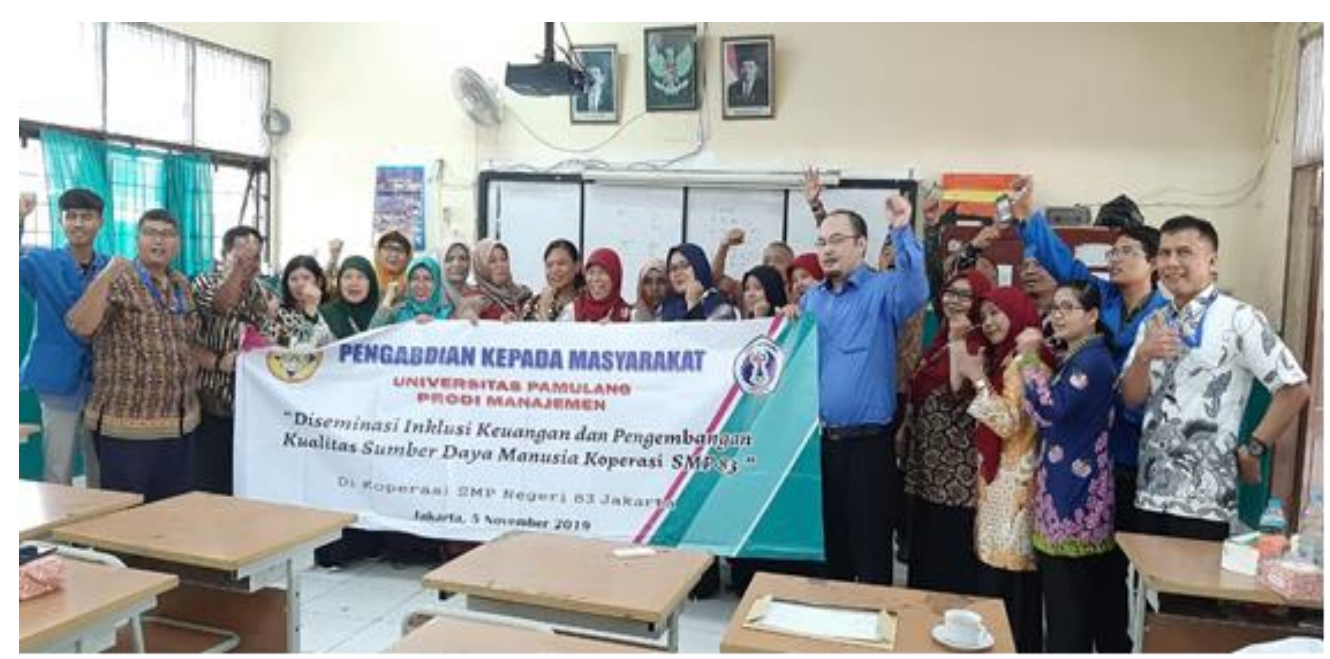

Gambar 2. Foto Bersama UNPAM dengan SMP 83

Beberapa langkah yang ditempuh untuk melaksanakan solusi terhadap permasalahan yang akan dilakukan adalah beberapa hal berikut ini :

1. Sosialisasi Program

Cara yang akan ditempuh untuk mensosialisasikan program penyuluhan adalah dengan mengunjungi koperasi dan memberitahu bahwa akan ada pelatihan dan penyuluhan berupa Pengabdian Kepada Masyarakat dari Dosen UNPAM.

2. Koordinasi

Koordinasi dilakukan antara panitia PKM Dosen UNPAM dengan Koperasi SMP 83. Perihal yang dikoordinasikan adalah rancangan kegiatan yang diajukan serta kesepakatan untuk pelaksanaan program.

3. Pelaksanaan Program

Program kegiatan PKM akan dilakukan di koperasi SMP 83 dengan cara melakukan penyuluhan dan pelatihan.

4. Evaluasi

Evaluasi dilakukan ditempat dengan menggunakan games-games dan kuis-kuis berhadiah.

\section{HASIL DAN PEMBAHASAN}

Berikut ini adalah hasil dan pembahasan dan kegiatan pengabdian masyarakat yang telah dilakukan pada bulan Desember 2019 :

1. Acara dibuka dengan upacara pagi, dimana pada saat ini diberikan berbagai macam sambutan, baik dari pihak SMPN 83 maupun dari pihak UNPAM. Setelah itu, acara dilanjutkan didalam ruangan dengan memberikan pembekalan materi kepada para peserta PKM yang terdiri dari para guru dan anggota koperasi SMPN 83.

2. Materi yang pertama diberikan oleh narasumber adalah tentang Inklusi keuangan. Yaitu pengetahuan tentang produk perbankan dan pengetahuan tentang bisnis E-Commerce. Materi selanjutnya yang diutarakan oleh narasumber yang sama yaitu Arif Surahman, adalah mengenai pengembangan 
sumber daya manusia dengan mengajarkan cara mengingat dengan menggunakan metode Mnemonics dan metode lainnya yang dikembangkan sendiri oleh narasumber.

3. Setelah semua materi diutarakan, maka dilakukan quis dan permainanpermainan. Tujuannya adalah untuk menguji pemahaman peserta mengenai materi yang sudah diberikan.

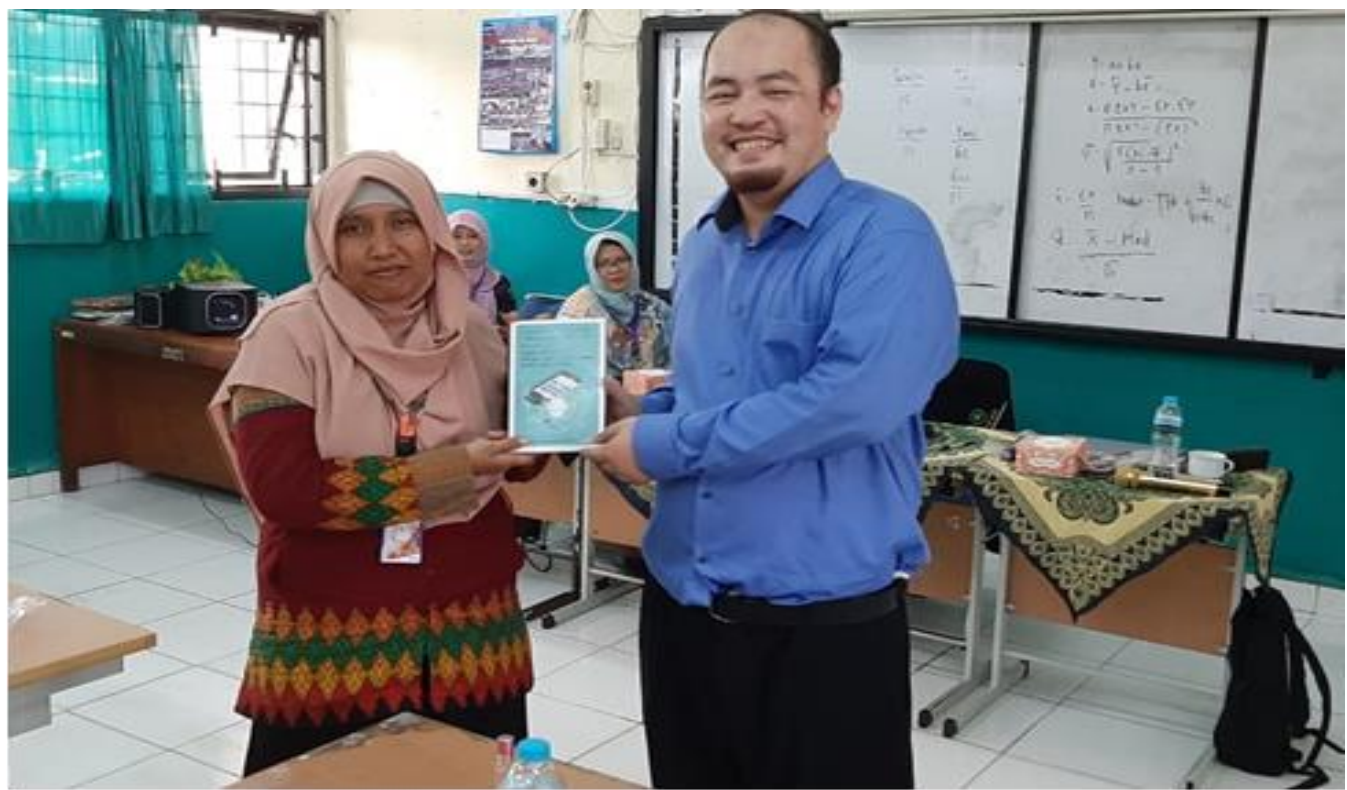

Gambar 3. Simbolis Pemberian Plakat

\section{KESIMPULAN DAN SARAN}

Perlu adanya program ekstrakulikuler dilingkungan koperasi SMPN 83 yang dapat digunakan untuk mengembangkan lebih lanjut mengenai kerjasama dengan dunia perbankan dan kerjasama lebih lanjut mengenai pengembangan mutu sumber daya manusia dengan Universitas Pamulang. Selain itu diperlukan juga untuk mengundang praktisi perbankan untuk kegiatan PKM berikutnya, supaya potensi koperasi SMPN 83 untuk melakukan kolaborasi dengan dunia perbankan dapat langsung terfasilitasi.

Saran yang dapat kami berikan terhadap PKM selanjutnya adalah perlu diadakan sesi tanya jawab yang lebih panjang dan waktu pemberian materi yang lebih lama. Namun memang hal ini terhalang dengan kesibukan mengajar di SMP tersebut. 


\section{DAFTAR PUSTAKA}

A Sobarna, S Hambali, S Sutiswo, D Sunarsi. (2020). The influence learning used ABC run exercise on the sprint capabilities. Jurnal Konseling dan Pendidikan 8 (2), 67-71

Astutik, Y. ( 2019, Oktober 3). https://www.cnbcindonesia.com. Dipetik 2019, dari https://www.cnbcindonesia.com/market/20191015210700-17-107298/ojkyakin-target-inklusi-keuangan-75-tercapai-tahun-ini.

D Sunarsi. (2014). Pengaruh Gaya Kepemimpinan, Motivasi dan Disiplin Kerja Terhadap Kinerja Pendidik. Universitas Pamulang

Fajar, S. (2016, Oktober 3). https://kalsel.antaranews.com/. Diambil kembali dari https://kalsel.antaranews.com/berita/39614/koperasi-perlu-kerjasamaperbankan-tanpa-agunan.

Gumilar, I., Sunarsi, D. (2020). Comparison of financial performance in banking with high car and low car (Study of banks approved in the kompas 100 index for the period 2013-2017). International Journal of Psychosocial Rehabilitation. Volume 24 - Issue 7

Maddinsyah, A., Sunarsi, D., Hermawati, R., Pranoto. (2020). Analysis of location selection effect on the user decision that influcence the success of the service business of micro, small and medium enterprise (MSME) in bandung timur region. International Journal of Advanced Science and Technology. Vol. 29 No. 06

Purwanti, P., Sarwani, S., \& Sunarsi, D. (2020). Pengaruh Inovasi Produk Dan Brand Awareness Terhadap Keputusan Pembelian Konsumen Pada PT. Unilever Indonesia. Inovasi, 7(1), 24-31.

Sunarsi, D., \& Asmalah, L. (2018). Pelatihan Manajemen Pengembangan Diri Bagi Penerima Beasiswa RZIS UGM Dan Dompet Shalahuddin Jogjakarta. Jurnal Pengabdian Dharma Laksana, 1(1), 51-60.

Sunarsi, D., \& Erlangga, A. (2020). The Effect of Leadership Style and Work Environment on the Performance of Stationary Pump Operators in the Water Resources Office of West Jakarta City Administration. International Journal of Advances in Social and Economics, 2(3).

Sunarsi, D., Kustini, E., Lutfi, A. M., Fauzi, R. D., \& Noryani, N. (2019). Penyuluhan Wirausaha Home Industry Untuk Meningkatkan Ekonomi Keluarga Dengan Daur Ulang Barang Bekas. BAKTIMAS: Jurnal Pengabdian pada Masyarakat, 1(4), 188-193.

Sunarsi, D., Kusjono, G., \& Nuryana, I. (2019). Pelatihan Manajemen Penguasaan Kelas Dan Pembuatan Bahan Ajar Bagi Tenaga Pengajar Sukarela Taman Belajar Kreatif Mekarsari. Jurnal Pengabdian Dharma Laksana, 2(1), 41-44. 